\title{
UMA NOVA ESPÉCIE DE OXAEA KLUG (OXAEINAE, ANDRENIDAE, HYMENOPTERA) DO SUL DO BRASIL ${ }^{1}$
}

\author{
Vinalto Graf $^{2}$
}

\begin{abstract}
A NEW SPECIES OF OXAEA KLUG (OXAEINAE, ANDRENIDAE FROM SOUTH BRAZIL. Oxaea mourei, sp. $n$ is described, from Paraná State, Brazil. This new species is most closely related to $\mathbf{O}$. schwarzi. They may be easily distinguished from each other since the hairs in $\mathbf{O}$. mourei are yellow-golden while those of $\mathbf{O}$. schwarzi are mostly black. The eyes of the male in $\mathbf{O}$. schwarzi are strongly convergent above and those of $\mathbf{O}$. mourei are weakly diverging above.

KEY WORDS. Oxaea, Andrenidae, Hymenoptera, Taxonomy
\end{abstract}

As abelhas do gênero Oxaea Klug, 1807 constituem um pequeno grupo de espécies muito antigas e especializadas da Região Neotropical. O holótipo desta nova espécie, descrita em homenagem ao Pe. Jesus S. Moure, no seu octagésimo aniversário, foi coletado nos "Campos Gerais" ao lado dos arenitos de Vila Velha, Ponta Grossa. Parecia uma Caupolicana Spinola, 1851 quando pousou numa haste de gramínea naquele entardecer de sábado, quando com os Drs. Theodore B. Mitchell e Sebastião Laroca, os companheiros daquele dia, estávamos preparando o retorno à Curitiba. As medidas entre parêntesis são em centésimos de milímetros.

\section{Oxaea mourei, sp.n}

Holótipo macho. Coloração preta. Tergos metasomáticos com as depressões marginais I-V lisas, brilhantes, com certo reflexo metálico. Asas lavadas de fusco-amarelo-pálido, as tégulas ferrugíneo-amareladas, com áreas internas escurecidas. Lábio, maxilas, extremidades distais dos fêmures, as tíbias e tarsos fusco-enegrecidas.

Pilosidade dourada, muito densa, longa, aveludada, mais viva na parte superior do mesosoma; mais clara nas genas, ocípicio, clípeo, labro, parte inferior da fronte, áreas látero-ventrais do meso e metasoma e dos tergos I, V, VI e VII; enegrecida e curta nos tergos metasomáticos II, III e parte anterior do IV; as margens distais dos tergos VI e VII com densa franja de pelos curtos; glabras: área mediana do labro, área distal mediana do clípeo, fóveas faciais

1) Contribuição número 749 do Departamento de Zoologia, Universidade Federal do Paraná.

2) Departamento de Zoologia, Universidade Federal do Paraná, Caixa Postal 19020, 81531-970 Curitiba, Paraná, Brasil. 
(áreas paraoculares superiores) e as depressões marginais dos tergos I a VI.

Pontuação densa na fronte, o vértice com pontos esparsos no meio e muito esparsos nos lados; as áreas paraoculares superiores não pontuadas, finamente reticuladas e com delicadas rugas transversais; área supraclipeal com pontuação muito densa, mas esparsa no meio. Clípeo com pontos muito esparsos no disco, densos a muito densos e pouco definidos nas áreas laterais e sem pontuação, liso e brilhante na área distal, junto a articulação do labro; os intervalos entre os pontos no disco micro-reticulados a coriáceos. Labro sem pontuação, micro-reticulado, mas com pontos bastante esparsos nos lados e na área distal, esta lisa e brilhante. Mesosoma com pontuação muito densa, mais esparsa no disco do mesoscuto e sem pontuação em estreita faixa média do metanoto; propódeo com densa pontuação na área basal mas o disco com pontuação esparsa. Tergos, nas partes basais, com pontuação densa e fina, mais esparsa e com pequenas áreas sem pontuação nos discos dos tergos III a V; a pontuação invade as depressões marginais nos tergos II a IV; a depressão marginal do tergo VI com estrias longitudinais e pontos esparsos na área distal. Tergo VII com fraca carena longitudinal e área mediana coriácea-reticulada, os lados com pontos esparsos, grossos e alongados para trás.

Cabeça mais larga que longa (608: 442) e um pouco mais estreita que o mesosoma (667). As órbitas internas convergentes até o nível dos ocelos laterais e para cima um pouco divergentes até o vértice, a distância interorbital inferior mais longa que a interorbital média e esta mais curta que a superior (352: 252: 260); a mandíbula um pouco mais curta que o comprimento do olho (336: 400); área malar muito estreita, seu comprimento a metade do menor diâmetro do primeiro flagelômero (008: 016). Mandíbulas com dente basal bem definido, com sua margem distal quase vertical, e o segundo aproximadamente na metade da mandíbula (160:336). Clípeo protuberante com comprimento um pouco mais que a metade da largura (192: 360), a distância alveolorbital a metade da distância interalveolar (048: 100) e esta maior que a distância clipeocelar (100: 084). Ocelo médio com diâmetro transversal maior que a distância interocelar (040: 032). O primeiro flagelômero mais longo que o escapo (120: 094) e quase igual aos comprimentos dos quatro seguintes e do último (018: 020: 020: 026: 042).

Comprimento total aproximado: $19,50 \mathrm{~mm}$. Comprimento da asa anterior: $14,50 \mathrm{~mm}$. Largura da cabeça: $6,08 \mathrm{~mm}$. Largura do mesosoma, entre os bordos externos das tégulas: 7,50 mm.

Alótipo. Preta, com as depressões marginais dos tergos metasomáticos I a IV brilhantes, com fracos reflexos verde-metálicos. Asas lavadas de fusco, mais enegrecidas que as dos machos, com as tégulas ferrugíneo-amareladas enegrecidas nas áreas internas.

Pilosidade como nos machos, com coloração dourado-laranja no dorso do mesosoma, mais desenvolvida e esbranquiçada principalmente nas partes internas das pernas posteriores; enegrecida, mais curta, simples, nos tergos I a III, cobrindo as depressões marginais; estas com alguns pontos finos, esparsos 
nos lados e nas áreas basais dos tergos II a IV; tergos II a V com estreita faixa longitudinal média sem pontuação; tergo $\mathrm{V}$ com a depressão marginal com estrias alongadas e pontos esparsos, a franja de pelos marginais curtos, dourados, porém mais larga que nos machos. A distância interorbital inferior mais longa que a interorbital média e esta um pouco mais curta que a superior (376: 352: 360).

Comprimento total aproximado: $21,00 \mathrm{~mm}$. Comprimento da asa anterior: $15,00 \mathrm{~mm}$. Largura da cabeça: $6,50 \mathrm{~mm}$.

Material examinado: Holótipo macho, Brasil: Paraná, Ponta Grossa (Vila Velha), X/1965, V. Grafleg. Alótipo, Paraná, Campo Mourão, 10/X/1982, A. Salvadori leg. Parátipos, dois machos, Paraná, Jaguariaíva, 03/XI/1972, J.S. Moure e F. Giacomel leg. Depositados na Coleção de Entomologia Pe. J.S. Moure, do Departamento de Zoologia da Universidade Federal do Paraná, Curitiba.

Discussão taxonômica. Entre as espécies de Oxaea, O. mourei sp.n. pertence ao grupo O. schwarzi Moure \& Seabra, 1962 por apresentar os tergos abdominais pretos, sem fortes cores verde-metálicas, clípeo e labro sem cores amarelas nos machos, ocelo médio não deprimido e clípeo e área supraclipeal em nível distinto ao da fronte nas fêmeas. Distingue-se facilmente das espécies O. schwarzi, O. alvarengai Moure \& Urban, 1963 e O. rufa Friese, 1899 pela pilosidade dourada em seu corpo. Aproxima-se de $O$. schwarzi pelas semelhanças no dente basal da mandíbula e na genitália, mas diferem nos gonóstilos sem tubérculos, nas órbitas internas, quase retas, e convergentes para o vértice em $O$. schwarzi; $O$. mourei tem os gonóstilos com tubérculos, as órbitas internas um pouco divergentes para o vértice e a distância interorbital superior dos machos bem mais larga $(2,64 \mathrm{~mm})$ do que em $O$. schwarzi $(0,80 \mathrm{~mm})$.

AGRADECIMENTOS. Agradeço à Prof ${ }^{\circledR}$ Danúncia Urban a leitura dos originais.

\section{REFERÊNCIAS BIBLIOGRÁFICAS}

FRIESE, H. 1899. Monographie der Bienengattungen Megacilissa, Caupolicana und Oxaea. Ann.K.K.Naturhisto.Hofmus. 14: 239-246.

HURD JR., P.D. \& E.G. LINSLEY. 1976. The Bee Family Oxaeidae with a Revision of the North American Species (Hymenoptera: Apoidea). Smiths. Contr. Zool. 220: 1-75.

MOURE, J.S. \& C.A.C. SEABRA. 1962. A new species of the genus Oxaea from Brazil (Hymenoptera:Apidae). J.N.Y. Ent. Soc. 70: 235-238.

MOURE, J.S. \& D. URBAN. 1963. Uma nova espécie de "Oxaea" de Mato Grosso, Brasil (Hymenoptera, Apoidea). Rev. Brasil. Biol. 23 (4): 361-364.

Recebido em 02.XI.1992; aceito em 07.VI.1993. 